1.

Repút Nó. BMI-1151

Metallurgy and Ceramics

(TID-4500, 12th Ed.)

Contract No. W-7405-eng-92

FABRICATION OF MOLYBDENUM SHEET

by

John R. Van Orsdel

Roland B. Fischer

December 5, 1956

BATTELLE MEMORIAL INSTITUTE

505 King Avenue

Columbus 1, Ohio 


\section{DISCLAIMER}

This report was prepared as an account of work sponsored by an agency of the United States Government. Neither the United States Government nor any agency Thereof, nor any of their employees, makes any warranty, express or implied, or assumes any legal liability or responsibility for the accuracy, completeness, or usefulness of any information, apparatus, product, or process disclosed, or represents that its use would not infringe privately owned rights. Reference herein to any specific commercial product, process, or service by trade name, trademark, manufacturer, or otherwise does not necessarily constitute or imply its endorsement, recommendation, or favoring by the United States Government or any agency thereof. The views and opinions of authors expressed herein do not necessarily state or reflect those of the United States Government or any agency thereof. 


\section{DISCLAIMER}

Portions of this document may be illegible in electronic image products. Images are produced from the best available original document. 


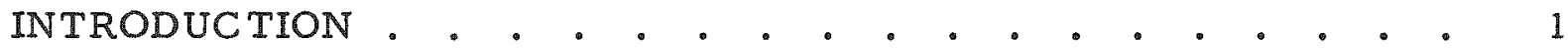

EXPERIMENTAL WORK . . . . . . . . . . . . . . . 2

Recrystallization Experiments . . . . . . . . . . . 2

Investigation of Fabricating Techniques . . . . . . . . 5

Bend Testing as a Measure of Ductility . . . . . . . . 5

Rolling Studies . . . . . . . . . . . . . . 5

Heat Treatment to Improve Ductility . . . . . . . . . 7

CONCLUSIONS . . . . . . . . . . . . . . . . . 10 


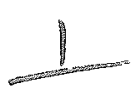

\title{
FABRICATION OF MOLYBDENUM SHEET
}

\author{
by
}

John R. Van Orsdel and Roland B. Fischer

The objective of the research described in this report was to try to find a method of fabricating commercial molybdenum into 1/16-in. thick sheet which would have good room-temperature ductility. An additional condition which was desired of the final sheet was that the grain structure should not be fibered.

The data presented strongly indicate that careful rolling and heattreating procedures will produce sheet capable of 90 -deg bends, transverse to the rolling direction, at room temperature. Furthermore, the scattering of results of the bend test was found to be significantly influenced by the rolling procedure.

The variables which were found to be operative in determining the ductility of the final material are as follows:

(1) Initial rolling iemperature

(2) Final rolling temperature

(3) Rate of ingot reduction

(4) Ingot thickness at the beginning of the finish-rolling step

(5) Heat treatment time and temperature.

It was also found that the ductility of the final sheet was not destroyed by heating the sheet for $115 \mathrm{hr}$ at $1800 \mathrm{~F}$. However, higher long-time holding temperatures did destroy the ductility by what is believed to be complete recrystallization.

No evidence of fibering was revealed in the microstructure of the ductile material.

\section{INTRODUCTION}

Molybdenum has two well-known characteristics which have severely retarded its use in pure form. These are its tendency to form a volatile oxide above $850 \mathrm{~F}$, and its poor room-temperature ductility under certain conditions fabrication and use. Reasonably ductile commercial molybdenum is produced as a wrought material having a heavily fibered grain structure. In some applications, the fibered structure is undesirable, however, because sheet of this type often tends to separate into laminae 
when welded or severely bent. Also recrystallization of the fibered structure at high temperatures results in brittleness at room temperature.

This research was directed toward the development of fabrication techniques which would yield molybdenum sheet, approximately $1 / 16$ in. in thickness, of good room-temperature ductility, but which would be free of the fibered type of structure mentioned above.

The molybdenum used in the experimental work was obtained from the Climax Molybdenum Company. This material was in the form of an extrusion which had been made from a commercial arc-cast ingot containing $0.02 \mathrm{w} / 0$ carbon. Since the entire program was conducted on material taken from the same extrusion, the effects of composition variables are believed to have been minimized.

\section{EXPERIMENTAL WORK}

The prevalence of brittle weldments in molybdenum sheet has been a great deterrent to its use in high-temperature reactors. Usually, the most ductile forms of commercial molybdenum (highly fibered) become quite brittle upon welding. Two phenomena are commonly associated with this brittleness: a coarse grain structure in the weld metal and a recrystallized fine grain structure in the heat-affected zone. Figure 1 is a photomontage of a typical weld and adjacent area in 1/16-in. -thick molybdenum sheet. Weldments with this structure have fair room-temperature bend ductility.

The presence of a fairly fine-grained structure in the heat-affected zone, shown in Figure 1, suggested the possibility of recrystallizing commercially available fibered molybdenum sheet. Such recrystallization might be expected to eliminate the exfoliation tendencies commonly associated with the fibered material.

\section{Recrystallization Experiments}

Some recrystallization experiments were conducted on strips of fibered molybdenum ( 0.060 by $1 / 4$ by $1-3 / 4$ in.) heated in vacuum. These experiments indicated that a recrystallization time of approximately $1 / 2$ min at 3100 to 3300 Fould produce a mixed grain size of ASTM 4 through 8. Longer times or higher temperatures resulted in excessive grain growth; use of lower temperatures did not result in random orientation. The material thus treated was completely brittle at room temperature and, therefore, this approach to the problem was abandoned. 
FIGURE 1. ALTERATION OF GRAIN STRUCTURE IN FIBERED MOLYBDENUM BY WELDING

Extreme left, parent metal followed by extended recrystallized zone with coarse grain structure of the weld metal at

grain structur
extreme right.

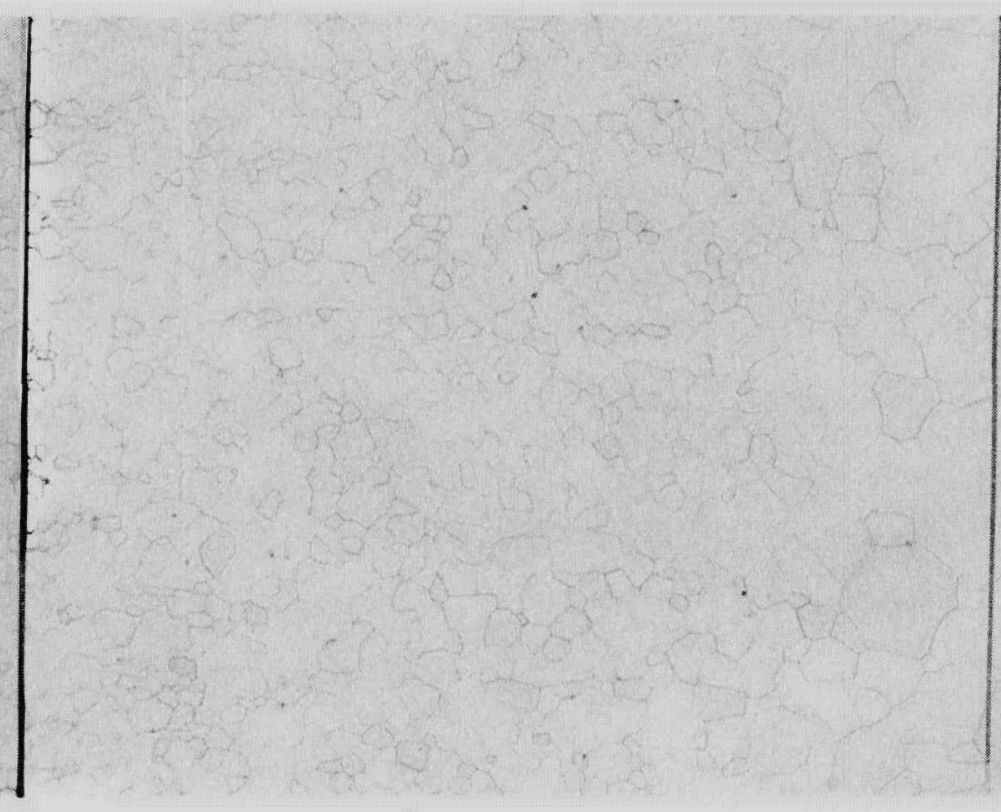

- 
Investigation of Fabricating Techniques

At the conclusion of the above work, it was decided to try to develop a fabricating technique which would be conducive to good ductility. Therefore, an extruded and recrystallized arc-cast carbon-deoxidized molybdenum ingot containing 0.02 w/o carbon was obtained as the starting material. This ingot was 3-9/16 in. in diameter by $10-1 / 2$ in. 1ong, and supplied all of the material used in the remainder of the program. Preparation of billets for rolling studies consisted of forging the extruded material to approximately 1 by $1-1 / 4$ in. billets at 2800 to $2900 \mathrm{~F}$.

Bend Testing as a Measure of Ductility

A simple bend test conducted at room temperature was used to evaluate ductility in the finished sheet. The bending device was operated by an electric motor which produced a deflection at the center of the specimen of 1 in. per min. The specimens were supported between two round beams placed 5/8 in. apart. The radius of bend was $1 / 16$ in. The angle of bend which produced fracture of the specimen was the criterion of comparison for different fabricating techniques. The maximum bend angle obtainable with the equipment was 95 deg. All specimens were cut transverse to the rolling direction of the sheet and were approximately $1 / 16$ in. thick by $3 / 16$ in. wide. Specimens were $1-1 / 2 \mathrm{in.}$ long or longer and could be tested in several different places along the length.

\section{Rolling Studies}

The variables investigated during rolling, as to their effects on roomtemperature ductility, were rolling temperature and the rate of reduction per pass.

All rolling was done in air with reheating of specimens in a hydrogen atmosphere between each pass.

Table 1 summarizes the data obtained in the first rolling studies. These data seemed to indicate that ductility was favored by high rolling temperatures. However, later work suggested that more complete annealing at high rolling temperatures was the real reason for improved ductility in the specimen.

Metallographic examinations of another series of specimens, which was rolled at $3100 \mathrm{~F}$, disclosed that considerable cold work remained in 
TABLE 1. MOLTBDENUM ROLLING STUDIES

\begin{tabular}{|c|c|c|c|c|c|c|}
\hline \multirow[b]{2}{*}{ Ingot } & \multirow[b]{2}{*}{ Rolling Technique } & \multirow{2}{*}{$\begin{array}{l}\text { Metallographic } \\
\text { Examination of } \\
\text { Finished Sheet }\end{array}$} & \multicolumn{4}{|c|}{$\begin{array}{l}\text { Angle of Bend at Fracture, deg, } \\
\text { In Room-Temperature Bend Test } \\
\text { of Indicated Specimen }\end{array}$} \\
\hline & & & 1 & 2 & 3 & 4 \\
\hline 9 & $\begin{array}{l}\text { Rolled at } 2900 \text { F with approximately } \\
28 \text { per cent reduction per pass; } \\
\text { reheated after each pass; air cooled }\end{array}$ & $\begin{array}{l}\text { Duplex grain structure, } \\
\text { length of grains range } \\
\text { from } 0.002 \mathrm{in} \text {. to } 0.020 \mathrm{in} \text {. }\end{array}$ & 6 & 50 & 14 & 40 \\
\hline 10 & $\begin{array}{l}\text { Rolled at } 3100 \mathrm{~F} \text { with approximately } \\
28 \text { per cent reduction per pass; } \\
\text { reheated after each pass; air cooled }\end{array}$ & $\begin{array}{l}\text { Less tendency to duplex } \\
\text { grains, coarser, and } \\
\text { more elongated than in Ingot } 9\end{array}$ & 14 & 14 & 16 & 10 \\
\hline 11 & $\begin{array}{l}\text { Same as Ingot } 10 \text { except sheet was water } \\
\text { quenched after last pass; quench caused } \\
\text { some cracking }\end{array}$ & Structure similar to Ingot 10 & 12 & 16 & 16 & 10 \\
\hline 12 & $\begin{array}{l}\text { Rolled at } 2900 \mathrm{~F} \text { to } 1 / 4 \text { in. with } 20 \text { per } \\
\text { cent reduction per pass; rolled from } \\
1 / 4 \text { in. to } 0.070 \text { in. with } 5 \text { per cent } \\
\text { reduction per pass. }\end{array}$ & Very coarse, elongated grains & 20 & 6 & 6 & 2 \\
\hline 13 & $\begin{array}{l}\text { Same as Ingot } 12 \text { except temperature was } \\
\text { lowered to } 2800 \mathrm{~F} \text { when making the } 5 \\
\text { per cent reductions }\end{array}$ & Structure similar to Ingot 12 & 2 & 4 & 3 & 4 \\
\hline 14 & $\begin{array}{l}\text { Same as Ingot } 12 \text { except temperature was } \\
\text { lowered to } 2560 \mathrm{~F} \text { when making the } 5 \\
\text { per cent reductions }\end{array}$ & Structure similar to Ingot 12 & 0 & 2 & 2 & 20 \\
\hline
\end{tabular}


the specimens even after use of the high rolling temperature: probably a result of quenching by the rolls. Thus, a need for heat treatment following rolling became apparent.

\section{Heat Treatment to Improve Ductility}

A new schedule of processing for molybdenum sheet was planned and a third series of specimens was processed. Table 2 reveals that a considerable increase in room-temperature ductility was obtained by heat treatment. The use of lower rolling temperatures and of a finish-rolling step were thought to be beneficial. Optimum finish-rolling and heattreatment temperatures appeared to be of the order of $2200 \mathrm{~F}$. Further investigation of heat-treatment schedules were made on specimens of rolling histories similar to those given in Table 2 . In addition to the previously mentioned variables studied, Vickers hardness determinations were made on each specimen following heat treatment. Table 3 lists the results of the se tests.

The average angle of bend given in Table 3 is the average of nine bend tests made on triplicate specimens. The range of scatter as well as the average was used in evaluating the different fabricating procedures. These data indicate that Specimens 20,27,31, and 35 are of good ductility but of decreasing quality, as determined by scatter, in the order given. Of particular note is the fact that, in each case, the 1 -hr heat treatment at 2200 Fas most effective in promoting ductility. Also, finish rolling from $0.125 \mathrm{in}$. to the final thickness of $0.066 \mathrm{in}$. was more favorable than finish rolling from 0.100 in. Specimen 20, which had an initial reduction rate of 40 per cent per pass, shows the least spread in bend-test results and is believed to indicate an optimum processing procedure. Another interesting feature of these data is that those specimens with the highest Vickers hardnesses for the group showed the greatest ductility. Therefore, the Vickers hardness might be used as a control indicator for process annealing.

Since it was recognized from Table 3 that residual cold work was associated with the ductility of the specimens, it was decided to determine the degree of stability of ductility for three of the most ductile specimens at elevated temperatures (sufficient material of Specimen 20, which also showed excellent ductility was not available for this test). Table 4 is a presentation of these data. These data indicate that material can be produced which will remain ductile after long-time exposure at $1800 \mathrm{~F}$. It will be noted that Specimen 30 (Table 3) had a history similar to that of Specimen 20, the chief differences between them being in the rate of reduction in the initial rolling step and in the thicknesses of the billets at the start of the finish-rolling step. All specimens tested suffered some loss of ductility by exposure at $2200 \mathrm{~F}$ for $115 \mathrm{hr}$. It was not possible to obtain absolute verification and reproduction of all the 
TABLE 2. SUMMARY OF MOLYBDENUM PROCESSING SCHEDULES AND THEIR EFFECTS ON DUCTILITY( ${ }^{(a)}$

\begin{tabular}{|c|c|c|c|c|c|c|c|c|c|c|c|}
\hline \multirow[b]{4}{*}{ Specimen } & \multicolumn{4}{|c|}{ Rolling Schedule } & & & & & & & \\
\hline & \multicolumn{2}{|c|}{ Initial Reduction } & \multicolumn{2}{|c|}{ Final Reduction } & \multirow{2}{*}{\multicolumn{7}{|c|}{ Angle of Bend to Produce Fracture After Indicated Heat Treatment, deg }} \\
\hline & & Per Cent & & Per Cent & & & & & & & \\
\hline & $\begin{array}{c}\text { Temperature }(b), \\
F\end{array}$ & $\begin{array}{c}\text { per } \\
\text { Pass } \\
\end{array}$ & $\begin{array}{c}\text { Temperature } \\
\mathrm{F} \\
\end{array}$ & $\begin{array}{c}\text { per } \\
\text { Pass } \\
\end{array}$ & $\begin{array}{c}\text { As } \\
\text { Rolled }\end{array}$ & $\begin{array}{c}1600 \mathrm{~F} \\
1 \mathrm{hr}\end{array}$ & $\begin{array}{c}1800 \mathrm{~F} \\
1 \mathrm{hr}\end{array}$ & $\begin{array}{l}2000 \mathrm{~F} \\
30 \mathrm{Min} \\
\end{array}$ & $\begin{array}{l}2200 \mathrm{~F} \\
30 \mathrm{Min} \\
\end{array}$ & $\begin{array}{c}2600 \mathrm{~F}^{\circ} \\
5 \mathrm{Min} \\
\end{array}$ & $\begin{array}{c}2800 \mathrm{~F} \\
5 \mathrm{Min} \\
\end{array}$ \\
\hline 9 & 2900 & 22 & -- & - & 35 & 14 & 14 & 16 & 35 & 25 & 35 \\
\hline 10 & 3100 & 28 & - & $-\infty$ & 14 & 8 & 8 & 18 & 50 & 40 & 70 \\
\hline 15 & 3100 & 10 & $\infty$ & $-\infty$ & 0 & 6 & 4 & 2 & 6 & 6 & 2 \\
\hline 16 & 3100 & 20 & -. & -- & 0 & 0 & 4 & 4 & 3 & 14 & 5 \\
\hline $27(c)$ & 3100 & 40 & -. & $\infty$ & 6 & 35 & 2 & 8 & 18 & 18 & 4 \\
\hline 18 & 3100 & 50 & - & - & 10 & 12 & 0 & 2 & 8 & 42 & 14 \\
\hline $19 \mathrm{~A}$ & 2600 & 40 & 2200 & 10 & & 60 & & & 55 & & 26 \\
\hline $19 \mathrm{~B}$ & 2600 & 40 & 2400 & 10 & & & 12 & 40 & & 30 & \\
\hline $21 \mathrm{~A}$ & 2700 & 40 & 2200 & 10 & & 35 & & & 45 & & 10 \\
\hline $21 B$ & 2700 & 40 & 2400 & 10 & & & 33 & 35 & & 0 & \\
\hline $23 A$ & 2800 & 40 & 2200 & 10 & & 27 & & & 60 & & 20 \\
\hline 238 & 2800 & 40 & 2400 & 10 & & & 40 & 16 & & 12 & \\
\hline $25 \mathrm{~A}$ & 2900 & 40 & 2200 & 10 & & 0 & & & 65 & & 6 \\
\hline $25 B$ & 2900 & 40 & 2400 & 10 & & & 45 & 2 & & 30 & \\
\hline
\end{tabular}

(a) All bend tests were made at room temperature and perpendicular to the rolling direction. Radius of bend was $1 / 16$ in. and rate of deflection was 1 in. per min.

(b) When specimens were rolled at two different temperatures, the sheet bar was reduced to 0.1 in. in the initial rolling step and then to 0.07 in. in the final rolling step. Polishing before bending produced an average specimen thickness of 0.065 in.

(c) These specimens averaged $0.107 \mathrm{in}$. in thickness. 


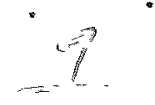

TABLE 3. EFFECT OF ROLLING HISTORY AIED HEAT TREATMENT UPON THE DUCTULTY OF MOLYBDENUM

\begin{tabular}{|c|c|c|c|c|c|c|c|c|c|}
\hline \multirow[b]{4}{*}{ Specimen } & \multicolumn{4}{|c|}{ Rolling Schedule } & & & \multirow{4}{*}{$\begin{array}{c}\text { Vickers Hardness } \\
\text { Number } \\
(10-\mathrm{Kg} \text { Load) }\end{array}$} & \multirow{4}{*}{$\begin{array}{c}\text { A vetage } \\
\text { Permanent } \\
\text { Bend Angle, } \\
\text { deg }\end{array}$} & \multirow{4}{*}{$\begin{array}{c}\text { Bend-Angle } \\
\text { Range, } \\
\text { deg }\end{array}$} \\
\hline & \multicolumn{2}{|c|}{ Initial Reduction } & \multicolumn{2}{|c|}{ Final Reduction } & \multirow{2}{*}{\multicolumn{2}{|c|}{ Hear Treatment }} & & & \\
\hline & & Per Cert & & Per Cent & & & & & \\
\hline & $\begin{array}{c}\text { Temperature, } \\
F\end{array}$ & $\begin{array}{l}\text { per } \\
\text { Pass }\end{array}$ & $\begin{array}{c}\text { Temperature, } \\
\text { F }\end{array}$ & $\begin{array}{l}\text { per } \\
\text { Pass }\end{array}$ & $\begin{array}{c}\text { Temperature, } \\
F\end{array}$ & $\operatorname{Time}_{\text {hr }}$ & & & \\
\hline \multirow[t]{3}{*}{20} & 2600 & 40 & 2200 & 10 & 2200 & 1 & 231 & 91 & 5 \\
\hline & & & & & 2600 & 1 & 190 & 26 & 52 \\
\hline & & & & & 2800 & 1 & 189 & 4 & 4 \\
\hline \multirow[t]{3}{*}{22} & 2700 & 40 & 2200 & 10 & 2200 & 1 & 244 & 20 & 53 \\
\hline & & & & & 2600 & 1 & 203 & 6 & 6 \\
\hline & & & & & 2800 & 1 & 196 & 6 & 4 \\
\hline \multirow[t]{3}{*}{24} & 2800 & 40 & 2200 & 10 & 2200 & 1 & 230 & 70 & 30 \\
\hline & & & & & 2600 & 1 & 192 & 9 & 12 \\
\hline & & & & & 2800 & 1 & 189 & 5 & 6 \\
\hline \multirow[t]{3}{*}{26} & 2900 & 40 & 2200 & 10 & 2200 & 1 & 246 & $95^{(2)}$ & \\
\hline & & & & & 2600 & 1 & 219 & 8 & 10 \\
\hline & & & & & 2800 & 1 & 198 & 5 & 4 \\
\hline \multirow[t]{2}{*}{27} & 2500 & 35 & 2200 & 10 & 2100 & 1 & & 84 & 35 \\
\hline & & & & & 2200 & 1 & & 90 & 16 \\
\hline \multirow[t]{2}{*}{28} & 2600 & 35 & 2200 & 10 & 2100 & 1 & & 75 & 87 \\
\hline & & & & & 2200 & 1 & & 83 & 44 \\
\hline \multirow[t]{2}{*}{29} & 2500 & 35 & 2200 & 10 & 2100 & 1 & & 59 & 70 \\
\hline & & & & & 2200 & 1 & & 77 & 43 \\
\hline \multirow[t]{2}{*}{30} & 2600 & 35 & 2200 & 10 & 2100 & 1 & & 67 & 65 \\
\hline & & & & & 2200 & 1 & & 89 & 45 \\
\hline \multirow[t]{2}{*}{31} & 2500 & 35 & 2100 & 10 & 2100 & 1 & & 72 & 55 \\
\hline & & & & & 2200 & 1 & & 90 & 55 \\
\hline \multirow[t]{2}{*}{32} & 2600 & 35 & 2100 & 10 & 2100 & 1 & & 77 & 45 \\
\hline & & & & & 2200 & 1 & & 75 & 50 \\
\hline \multirow[t]{2}{*}{33} & 2500 & 35 & 2100 & 10 & 2100 & 1 & & 42 & 40 \\
\hline & & & & & 2200 & 1 & & 77 & 40 \\
\hline \multirow[t]{2}{*}{34} & 2600 & 35 & 2100 & 10 & 2100 & 1 & & 71 & 55 \\
\hline & & & & & 2200 & 1 & & 84 & 55 \\
\hline \multirow[t]{2}{*}{35} & 2500 & 35 & 2000 & 10 & 2100 & 1 & & 86 & 35 \\
\hline & & & & & 2200 & 1 & & 88 & 65 \\
\hline
\end{tabular}

Note: Specimens $27,28,31$, and 32 were finish rolled from a 0.125 -in. thickness to $0.066 \mathrm{in}$. Specimens $29,30,33$, and 34 were finish rolled from a 0.100 -in. thickness to $0.066 \mathrm{in}$. Specimen 35 was finish rolled from a 0.250 in. thickness to 0.066 in.

(a) Only enough material for one bend test. 
results summarized in this report. However, it is believed that a significant amount of ductility can be obtained in wrought molybdenum by the procedures described in this report. Sheet which was processed by methods described for Specimens 20 and 30 , although coarse grained (ASTM 1-3), had good room-temperature ductility and was not fibered.

TABLE 4. EFFECT OF EXPOSURE TO ELEVATED TEMPERA TURES FOR 115 HR IN HYDROGEN ON THE ROOM-TEMPERATURE DUCTILITY OF MOLYBDENUM

\begin{tabular}{ccccc}
\hline & \multicolumn{2}{c}{$\begin{array}{c}\text { Permanent Bend Angle, deg, After Exposure } \\
\text { at Indicated Temperature }\end{array}$} \\
\cline { 2 - 6 } Specimen & $\frac{1800 \mathrm{~F}}{\text { Average }}$ & Range & $\frac{2200 \text { Average }}{\text { Avange }}$ \\
\hline 27 & 48 & 60 & 14 & 12 \\
30 & 92 & 15 & 15 & 10 \\
35 & 70 & 45 & 9 & 6 \\
\hline
\end{tabular}

CONCLUSIONS

Wrought molybdenum can be prepared in ductile form without fibering. Apparently, a small amount of residual cold work is necessary in the finished product. This cold work can be readily detected by Vickers hardness determinations. The residual cold work, as detected, is believed to indicate the optimum amount of recrystallization necessary to yield good roomtemperature ductility. Recrystallization of molybdenum seems to proceed rather sluggishly at $2200 \mathrm{~F}$. However, the work indicates that variations in prior processing history have significant effects on the recrystallization and subsequent ductility.

$J R V: R B F / c m$ 